\title{
PRINSIP-PRINSIP KEMUNCULAN DISIPLIN ILMIAH DALAM PEMIKIRAN WILHELM WUNDT (1832-1920) TENTANG PSIKOLOGI
}

\author{
Abdul Rokhmat Sairah \\ Fakultas Filsafat, Universitas Gadjah Mada \\ Email: Rokhmat-sairah@ugm.ac.id
}

Abstrak

Perkembangan ilmu merupakan sebuah keniscayaan yang ditandai melalui proses kelahiran disiplin ilmiah. Salah satu model kelahiran disiplin ilmiah adalah kemunculan psikologi yang ditandai oleh pendirian laboratorium oleh Wilhelm Wundt di Universitas Leipzig. Tulisan ini bertujuan untuk mengungkap prinsip-prinsip dalam kemunculan psikologi sebagai disiplin ilmiah. Penelitian ini dilakukan melalui studi kepustakaan dengan menggunakan metode analisis kefilsafatan terhadap sejarah psikologi dan pemikiran Wilhelm Wundt tentang psikologi, serta teori-teori perkembangan ilmu dalam filsafat ilmu. Hasil penelitian ini menunjukkan bahwa kemunculan psikologi sebagai disiplin ilmiah ditandai oleh beberapa prinsip yaitu: kebaruan, spesialisasi, kekhasan, heuristik, dan revolusioner.

Kata kunci: Sejarah Psikologi, Filsafat Ilmu, Wilhelm Wundt, Perkembangan Ilmu, Kemunculan Disiplin.

\section{Abstract}

The development of science is a necessity characterized by the emergence of scientific disciplines. A model of scientific discipline emergences is the emergence of psychology which took place with the establishment of a laboratory by Wilhelm Wundt at the University of Leipzig. This paper aims to reveal the principles in the emergence of psychology as a scientific discipline. This research is a literature study with the method of philosophical analysis of the history of psychology and Wilhelm Wundt's thoughts on psychology, as well as theories of the development of science in the philosophy of science. This study indicates that the emergence of psychology as a scientific discipline characterized by several principles: 
novelty, specialization, uniqueness, heuristic, and revolutionary.

Keywords: History of Psychology, Philosophy of Science, Wilhelm Wundt, Science Development, The Emergence of Discipline.

\section{PENDAHULUAN}

Ilmu merupakan salah satu instrumen penting dalam kehidupan manusia. Manusia membutuhkan ilmu untuk mengembangkan teknologi dan kebudayaan. Ilmu pada mulanya bersifat umum (general), meliputi berbagai aspek, namun dewasa ini mulai terspesialisasi ke dalam bagian-bagian tertentu. Ada banyak ragam ilmu yang berkembang saat ini. Hal itu memunculkan pertanyaan, mengapa terjadi demikian? Apa sesungguhnya yang disebut ilmu? Bagaimana karakteristik ilmu? Bagaimana seseorang dapat mengembangkan ilmu baru, atau bagaimana sesuatu hal dapat dipandang sebagai ilmu baru? Apa yang menjadi tolok ukur dan siapa penentunya? Pertanyaan-pertanyaan tersebut merupakan pertanyaan khas dalam kajian filsafat ilmu.

Sejarah ilmu mengungkapkan adanya proses layaknya organisme dalam perkembangan dan kemajuan ilmu. Proses itu dimulai dari embrio, dilanjutkan dengan kelahiran, dan kemudian berkembang menjadi ilmu yang telah dewasa, lalu pada gilirannya akan melahirkan ilmu baru kembali. Filsafat merupakan induk dari segala jenis ilmu sehingga dikenal dengan semboyan, "mater scientiarum" (induk ilmu). Filsafat disebut sebagai induk ilmu karena filsafat adalah ilmu yang pertama kali muncul, di samping itu kelahiran ilmu membutuhkan andil filsafat. Hal itu menunjukkan bahwa pada tataran tertentu filsafat dapat dikelompokkan ke dalam jenis ilmu, tetapi pada tataran yang lain filsafat tidak berhenti hanya sampai pada pencapaian ilmu. Bagaimana proses kelahiran ilmu dengan demikian menjadi menarik untuk diperhatikan, mengingat pesatnya perkembangan beragam jenis ilmu yang menghasilkan berbagai teknologi dan budaya dewasa ini. 
Eksplanasi tentang proses kelahiran ilmu dapat menjadi referensi bagi 'penemuan' (discovery) ilmu-ilmu baru di masa depan. Hal itu juga dapat menerangkan tentang proses yang terjadi dalam pengembangan sebuah disiplin ilmu serta memberi penjelasan tentang sifat/karakter sebuah ilmu secara spesifik maupun ilmuilmu secara umum. Ilmu tidak muncul secara tiba-tiba begitu saja melainkan telah melalui proses yang panjang. Persoalannya adalah apa yang menandakan peristiwa kelahiran suatu ilmu? Oleh karena itu, perlu diadakan penelitian tentang proses kelahiran sebuah ilmu.

Salah satu ilmu yang mengalami perkembangan pesat dan memiliki pengaruh yang cukup besar dewasa ini adalah psikologi. Paul Thagard (2007: ix) mengungkapkan bahwa psikologi sekarang menjadi bagian dari ilmu kognitif, studi interdisipliner tentang pikiran dan kecerdasan yang juga mencakup bidang neuroscience, kecerdasan buatan (artificial intelligence), linguistik, antropologi, dan filsafat. Neuroscience telah memberikan kontribusi eksperimental dan teoritis yang meningkat pesat untuk psikologi dalam dekade terakhir karena munculnya teknik pemindaian otak yang menyediakan cara untuk mengamati proses syaraf. Psikologi juga tumpang tindih dengan kecerdasan buatan (artificial intelligence) dalam pengembangan model pemikiran komputasi dan dengan linguistik dalam studi tentang bagaimana pikiran memahami dan menghasilkan bahasa.

Thomas Leahey (2018: 42) mengemukakan bahwa psikolog sebagai ilmuwan berusaha menjelaskan perilaku hewan dan manusia tanpa mengacu pada jiwa atau roh. Hal itu membawa mereka ke dalam konflik dengan tradisi kuno dan telah bertahan lama yang dianut oleh banyak psikolog sendiri tentang keyakinan pada jiwa supernatural. Ketegangan ini adalah masalah serius bagi psikologi kontemporer. Pernyataan Leahey menunjukkan bahwa psikologi kontemporer masih menghadapi persoalan yang telah berlangsung sejak zaman lampau. Hal ini menunjukkan bahwa psikologi sebagai sebuah kajian sebenarnya telah berlangsung sejak zaman kuno. Akan tetapi terjadi sebuah peristiwa penting dalam 
perkembangannya yang kemudian diklaim sebagai 'kelahiran' psikologi.

Sejarah psikologi menempatkan Wilhelm Maximilian Wundt (1832-1920) sebagai tokoh yang 'membidani' lahirnya ilmu tersebut. Dicky Hastjarjo (2009: 109) mengungkapkan bahwa psikologi menetapkan Wilhelm Wundt sebagai pendiri. Kelahiran psikologi tidak ditandai oleh tanggal lahir pendiri (1832) atau waktu terbit buku yang ditulis pendiri (Grundzuge der Physiologishen Psychologie terbitan 1874) tetapi berdasarkan waktu berdirinya sebuah laboratorium di Leipzig pada tahun 1879. Proses kemunculan psikologi sebagai sebuah disiplin baru cukup unik. Psikologi Wundt diklaim sebagai momentum kemunculan psikologi modern atau hadirnya sebuah disiplin baru. Kemunculan ini memiliki kemiripan dengan beberapa bidang ilmu lainnya yang menempatkan salah seorang tokoh sebagai pionirnya seperti Adam Smith (1723-1790) dalam ilmu ekonomi, Auguste Comte (1798-1857) dalam Sosiologi. Keunikan pada kemunculan psikologi karena tidak mengacu pada waktu terbitnya karya ilmiah fenomenal sang penemu, tetapi mengacu pada waktu berdirinya laboratorium.

Penelitian ini hendak menganalisis proses kelahiran psikologi dengan menelaah pemikiran Wilhelm Wundt (1832-1920) menggunakan pendekatan filsafat. Pendekatan filsafat yang digunakan dalam penelitian ini adalah salah satu kajian dalam filsafat ilmu yaitu perkembangan ilmu (science development). Penelitian ini mencoba untuk menjelaskan tentang kriteria kemunculan sebuah disiplin ilmu berdasarkan kajian terhadap peristiwa kemunculan psikologi.

Berdasarkan uraian tersebut di atas maka fokus kajian pada tulisan ini adalah: apa sumbangsih pemikiran Wilhelm Wundt yang menjadikannya dikenal sebagai 'bapak' psikologi? Apa kondisikondisi yang mendukung (sufficient condition) bagi lahirnya psikologi? Apa syarat-syarat yang dipenuhi (necessary condition) dalam kelahiran psikologi yang dapat berlaku juga bagi 'penemuan' ilmu yang lain di masa mendatang? 


\section{PEMBAHASAN}

\section{Latar Belakang Kemunculan Psikologi}

Kemunculan psikologi hingga diakui sebagai sebuah disiplin ilmiah bukan sesuatu yang terjadi begitu saja, melainkan melalui proses yang panjang. Proses tersebut bukan juga sesuatu yang terjadi dengan tanpa kesengajaan, tetapi tidak dapat juga dipandang sebagai sesuatu yang terencana meskipun terstruktur. Banyak hal yang melatarbelakangi kemunculan disiplin ilmiah ini. Subbab ini membahas hal-hal yang melatarbelakangi kemunculan psikologi sebagai disiplin ilmiah tersebut sebelum lebih lanjut menguraikan pemikiran Wilhelm Wundt tentang psikologi dan prinsip-prinsip kemunculan disiplin ilmiah berdasarkan pemikiran itu. Tujuan tersebut tidak dapat lepas dari pembahasan tentang sejarah psikologi.

Sejarawan psikologi berkebangsaan Amerika Serikat, Hilgard (1987), memberi julukan Wilhelm Wundt sebagai pendiri psikologi sebagai sebuah ilmu/pengetahuan laboratorium (Hastjarjo, 2009: 109). Wundt mengawinkan filsafat dengan fisiologi sehingga menjadi psikologi sebagai ilmu yang mempelajari mental (mind)/kesadaran (consciousness) dengan menggunakan metode eksperimen sebagai metode fisiologi/ilmu alam. Istilah psikologi eksperimen dan psikologi fisiologi dapat saling dipertukarkan pada masa lalu (Hilgard, 1987).

Robert W. Rieber (2013: ix) mengemukakan bahwa pada milenium baru ini layak untuk mempertanyakan, "mengapa mengkaji Wundt?" Banyak penulis selama bertahun-tahun sepeninggal Wundt melihat secara rinci karya dan pencapaian Wilhelm Wundt (1832-1920). Hal ini terutama terjadi pada sekitar tahun 1979, seratus tahun Institut Psikologi Eksperimental Leipzig, tempat kelahiran "program pascasarjana" psikologi. Lebih dari dua puluh tahun telah berlalu sejak saat itu, studi itu telah menarik perhatian dan memotivasi upaya berbagai sejarawan, filsuf, psikolog, dan ilmuwan sosial lainnya. Mereka telah mengambil manfaat dari pertanyaan yang diajukan sebelumnya tentang aspek 
teoritis, metodologis, sosiologis, dan bahkan politik yang mempengaruhi studi pikiran dan perilaku yang terorganisir. Mereka juga telah mengusulkan beberapa arah baru untuk penelitian dalam sejarah ilmu perilaku dan sosial. Buku ini membahas "bapak pendiri psikologi" yang digembar-gemborkan dengan memanfaatkan perspektif historiografik yang dihasilkan dalam dua puluh tahun.

Sejarawan psikologi hampir sepakat tentang satu hal, bahwa psikologi adalah ilmu yang relatif baru (Reed, 1982: 731-732). Beberapa ketidaksepakatan adalah kapan berawal? Apakah sejak E.H Weber, Fechner, Wundt, atau William James? Tetapi hampir tidak ada perbedaan pendapat dari proposisi bahwa psikologi sebagai disiplin ilmu kurang dari satu setengah abad. Banyak penulis sebelumnya sering membahas dalam kisah-kisah psikologi, tetapi mereka selalu disebut spekulan, atau filsuf, sebagai kebalikan dari ilmuwan. Reed mengusulkan untuk menunjukkan bagaimana sebuah ide kunci psikologis dari Descartes memiliki sejarah ilmiah yang luas dan kuat. Jika benar bahwa gagasan Cartesian ini memiliki pengaruh besar dalam sains, maka banyak klaim mengenai sejarah psikologi perlu dipertimbangkan kembali. Tidak semua yang terjadi dalam psikologi sebelum abad kesembilan belas bersifat spekulatif, dan tidak semua yang terjadi kemudian bersifat ilmiah. Lebih penting lagi, jika gagasan Descartes (1596-1650) telah menjadi perhatian utama selama beberapa ratus tahun penelitian, itu harus diperlakukan sebagai klaim penting tentang cara dunia ini bekerja, sebagai hukum alam.

Geoff Bunn (2017: 10) dalam penelitiannya berjudul "Wilhelm Wundt and The Emergence of Scientific Psychology" memandang pada celah antara apa yang Wundt harapkan untuk psikologi dan apa yang sebenarnya terjadi. Bunn menyatakan bahwa pada pertengahan abad kesembilan belas, psikologi belum ada sebagai disiplin akademis formal. Francis Galton (1822-1911) dan Herbert Spencer (1820-1903), 'ahli sains Victoria yang kaya raya', mulai mengakui dan mengumpulkan data statistik tentang kemampuan individu serta membangun teori yang rumit tentang sifat manusia. 
Namun demikian, belum ada program gelar, jurnal akademis, atau laboratorium penelitian yang dikhususkan untuk psikologi.

Bunn (2017: 10) menambahkan bahwa seorang filsuf Amerika yang mahsyur, William James (1842-1910), pada tahun 1867 mengumumkan bahwa 'mungkin sudah waktunya bagi psikologi untuk mulai menjadi ilmu'. Beberapa pengukuran telah dilakukan di wilayah yang terletak di antara perubahan fisik pada saraf dan munculnya kesadaran, serta lebih banyak lagi yang mungkin terjadi. Hermann von Helmholtz (1821-1894) dan seorang pria bernama Wundt di Heidelberg sedang mengerjakan tantangan yang telah James letakkan. Wundt memberi tahu tunangannya pada tahun 1872 bahwa ia bermaksud untuk mengambil ajakan provokatif James dan mengabdikan dirinya pada 'daerah perbatasan yang agak mencurigakan antara fisiologi dan filsafat'.

Bunn (2017: 10) mengungkapkan bahwa Wundt telah mendedikasikan paruh terakhir hidupnya untuk bidang perbatasan yang agak mencurigakan antara fisiologi dan filsafat, dan kemudian dikenal sebagai 'bapak psikologi eksperimental'. Buku Wundt "Principles of Physiological Psychology" (1874) adalah buku teks psikologi yang pertama. Ia membuka laboratorium pertama yang secara eksklusif dikhususkan untuk eksperimen psikologis di Universitas Leipzig pada tahun 1879, peristiwa yang telah ditetapkan untuk menandai kelahiran psikologi sebagai disiplin independen. Ia meluncurkan jurnal akademis, Philosophical Studies, pada tahun 1883 untuk menerbitkan hasil penelitian kelompok Leipzig.

Latar belakang kemunculan psikologi tak terlepas dari pengaruh ilmu-ilmu lain misalnya Filsafat, Biologi, Fisiologi, Sosiologi, Antropologi (Jahja, 2011: 3). Ilmu-ilmu tersebut berpengaruh terhadap psikologi dengan meletakkan landasan epistemologis berupa kriteria hubungan subjek dan objek, metode yang digunakan, serta lingkup penyelidikan. Weiten (2017:3) mempertegas bahwa induk psikologi adalah filsafat dan fisiologi. Sejarawan psikologi yang lain, Schultz (2014: 56) menyatakan 
bahwa landasan filosofis psikologi baru adalah positivisme, materialisme dan empirisisme.

Psikologi pada awalnya sebagai bagian dari filsafat. Objek psikologi beberapa kali didefinisikan secara berbeda, baik sebagai "jiwa", "substansi mental", "pikiran", dan sebagainya. Psikologi dipandang sebagai penyelidikan kesadaran atau "pengalaman batin", yang berbeda dengan penyelidikan ilmu alam tentang realitas terindera dunia eksternal pada akhir abad ke-18 hingga awal abad ke-19. Immanuel Kant (1724-1804) kemudian menolak terhadap gagasan psikologi 'jiwa' yang spekulatif, rasional, apriori yang dicontohkan oleh Christian Wolff (1679-1754), dan mencoba untuk menghentikan setiap upaya ke dalam studi empiris tentang kesadaran. Kant dalam Metaphysical Foundations of Natural Science berpendapat bahwa psikologi empiris tidak dapat menjadi ilmu pasti karena fenomena yang ingin dijelaskannya tidak dapat diungkapkan secara matematis (Kitcher 1990: 11). Kant menambahkan bahwa psikologi tidak pernah dapat menjadi ilmu eksperimental karena tidak mungkin "mengisolasi" pemikiran yang berbeda (Kitcher 1990: 11).

Satu-satunya akses ke fenomena pengalaman batin adalah introspeksi, ipso facto (yang oleh kenyataan itu sendiri) mengubah fenomena itu. Artinya jika seseorang mencoba melalui introspeksi untuk mempelajari tentang bagaimana rasanya menjadi sedih, fenomena kesedihan menjadi sesuatu yang berbeda, yaitu "fenomena kesedihan saya - dipelajari - oleh - saya" (Kitcher 1990: 11). Jadi, psikolog menemukan objek mereka dinyatakan di luar batas penyelidikan yang dimungkinkan dan metode mereka menjadi sia-sia.

Penolakan Kant terhadap psikologi diiringi kemajuan dalam fisiologi manusia terutama tentang sistem sensorik. Ahli fisiologi, Ernst Heinrich Weber (1795-1878), menerbitkan penemuan mengejutkan dalam karyanya "De tactu". Eksperimennya pada sensasi terhadap "berat" telah membawanya untuk menemukan bahwa diperoleh rasio konstan antara stimulus yang diberikan di satu sisi dan stimulus kedua yang lebih besar agar perbedaan antara 
dua stimulus menjadi dapat terlihat, tidak peduli berapapun besarnya stimulus pertama. Dengan kata lain, jika stimulus pertama adalah intensitas $I$ maka $\Delta I$ adalah jumlah yang harus ditingkatkan agar perbedaannya terlihat, rasio antara $I$ dan $\Delta I$ adalah konstan $(k)$ : $\frac{\Delta I}{I}=k$ (Wundt, 1921: 186). Persamaan ini kemudian dikenal sebagai Hukum Weber yang berperan penting dalam perkembangan psikologi.

Wilhelm Wundt kemudian menjadikan ilmu eksperimental psikologi. Wundt pada dasarnya mempertahankan pendekatan eksperimental dan pada saat yang sama melampaui interpretasi fisis murni eksperimen fisiologis dengan berargumen bahwa setidaknya eksperimen pada manusia dapat mengungkapkan hukum seperti keteraturan realitas mental (psikologis). Jadi, Wundt seakan mendirikan "ilmu hibrida" yang asal keduanya dinyatakan dalam sebutan Wundt untuk itu, "physiological psychology"/ "psikologi fisiologis" (Ben-David \& Collins 1966: 459).

Latar belakang kemunculan psikologi berdasarkan uraian di atas dapat dirinci ke dalam beberapa poin berikut:

1. Perkembangan lapangan penyelidikan dan pengetahuan awal yang memicu kemunculan psikologi seperti: filsafat, fisiologi, dan biologi.

2. Diskursus wacana pengetahuan antara rasionalisme dan empirisisme.

3. Pengaruh pemikiran Immanuel Kant tentang penolakannya terhadap psikologi empiris.

4. Kemajuan metode penelitian, instrumen, formulasi hukum, seperti hasil kajian Ernst Heinrich Weber.

\section{Pemikiran Wilhelm Wundt tentang Psikologi}

Wilhelm Wundt dikenal memiliki pemikiran yang luas dengan sistem yang lengkap. Pemikiran seseorang tidak dapat dipisahkan dari konteks zaman, pengaruh lingkungan, dan latar belakang pendidikannya. Pembahasan tentang pemikiran Wundt di sini dengan demikian tidak dapat juga dilepaskan dari masa 
hidupnya. Oleh karena itu pada kesempatan ini perlu dibahas terlebih dahulu secara singkat latar belakang kehidupan Wilhelm Wundt.

Wilhelm Maximilian Wundt lahir pada 16 Agustus 1832, putra seorang pendeta Lutheran di Neckarau, Baden, saat ini secara administrasi masuk wilayah Manheim, Jerman. Kehidupan keluarga orang tuanya dan masa sekolahnya tidak diketahui secara pasti meskipun dapat diduga bahwa dia menghadiri gimnasium di kota tetangga Mannheim, yang kemudian ia menjadi warga negara kehormatan pada tahun (1907). ia menghabiskan waktu dari tahun 1851 hingga 1856 di Universitas Tubingen (di mana pamannya sebagai Professor anatomi) Heidelberg, dan Berlin. Sebagian besar masa mahasiswanya tidak menunjukkan minatnya pada fisiologi, meskipun ia bekerja untuk Institut Johannes Miiller, tetapi lebih pada anatomi patologis di bidang medis murni. Ia menjadi asisten Klinik Medis di Heidelberg pada tahun 1855-1856, dengan karyanya yang pertama, "Untersuchungen über das Verhalten der Nerven in entzündeten und degenerierten Zustanden" (Investigasi Perilaku Syaraf pada Kondisi Meradang dan Merosot) didedikasikan untuk C.E Hasse, direkturnya (Titchener, 1921: 161).

Wundt menjadi dosen privat di Heidelberg pada tahun 1857. Subjek utamanya adalah fisiologi, tidak diketahui apakah pilihannya atau sebuah kecelakaan akademis. Dia tetap di posisi Itu, bekerja beberapa tahun sebagai asisten Helmholtz yang datang ke Heidelberg pada tahun 1858-1864, ketika ia diangkat menjadi dosen luar biasa. Magang Wundt untuk karir akademiknya bahkan lebih panjang dari Immanuel Kant. Ia menerima panggilan ke Zurich pada tahun 1874 untuk posisi filsafat induktif yang didirikan oleh F. A. Lange. Ia kemudian diangkat menjadi Professor filsafat di Leipzig pada tahun 1875. Ia tinggal dan bekerja selama empat puluh lima tahun di Leipzig, menjadi rektor pada tahun 1889 (hanya empat belas tahun setelah ia bergabung dengan fakultas filsafat), warga kehormatan kota pada tahun 1902, orator universitas pada hari peringatan lima ratus tahun 1909, tetap menjadi Professor sampai tahun 1917 dan kemudian meninggal di Grossbothen dekat 
Leipzig pada 31 Agustus 1920 dua minggu setelah genap berusia 88 tahun (Titchener, 1921: 162-163).

Pemikiran seseorang dapat ditelaah berdasarkan karyakaryanya, oleh karena itu untuk membahas pemikiran Wilhelm Wundt perlu diketahui karya-karyanya. Wilhelm Wundt menghasilkan banyak karya semasa hidupnya. Karya-karya tersebut ada yang berupa buku, artikel, surat, bahan ajar perkuliahan. Karya Wundt dapat juga ditemukan dalam bahasa Jerman sesuai dengan kebangsaannya dan dalam bahasa Inggris. Beberapa karya Wundt yang pernah diterbitkan (Kim, 2016) antara lain:

1. Textbook of Human Physiology (Buku teks Fisiologi Manusia) terbit pada tahun 1864

2. Principles of Physiological Psychology (Prinsip-Prinsip Psikologi Fisiologis) sebanyak 3 volume terbit tahun 1874.

3. Logic. An Investigation into The Principles of Knowledge and The Methods of Scientific, terbit tahun 1880.

4. On Psychological Methods terbit tahun 1883.

5. Ethics terbit tahun 1886.

6. System of Philosophy terbit tahun 1889.

7. Outlines of Psychology terbit tahun 1897

8. On Mental Causality and The Principle of Psycho-Physical Parallelism terbit tahun 1894.

Pemikiran Wilhelm Wundt tentang psikologi perlu dibedakan dengan pemikirannya dalam psikologi. Wundt sebagai pendiri psikologi memiliki proyeksi sendiri tentang ilmu yang tengah diusahakannya dan tanpa disadari baik secara langsung maupun tak langsung telah berfilsafat tentang psikologi. Oleh karena itu pemikiran Wundt tentang psikologi dapat dikatakan sebagai bagian tak terpisahkan dari bidang kajian filsafat psikologi yang berbeda dengan psikologi filsafati, meskipun Wundt sekaligus mengerjakan kedua hal tersebut. Filsafat psikologi menyangkut tentang landasan kerangka konseptual bangunan keilmuan psikologi, sedangkan psikologi filsafati menyangkut tentang keadaan-keadaan alamiah fenomena subjek yang diteliti. 
Pemikiran Wundt tentang psikologi terutama diarahkan pada hal-hal berikut:

1. Psikologi sebagai Ilmu eksperimental, hal Ini menyangkut tentang objek dan metode yang sesuai dengan psikologi;

2. Penelitian psikologi terhadap individu terutama diarahkan pada sensasi dan kesadaran (consciousness).

3. Kerangka teoretik psikologi eksperimental.

4. Kedudukan psikologi dalam susunan pengetahuan, hal Ini terkait dengan hubungan psikologi dengan ilmu-ilmu lainnya.

Wundt mengidentifikasi "fisiologis" dengan "psikologi eksperimental". Wundt memandang bahwa satu-satunya tujuan psikologi eksperimental adalah memberi deskripsi yang tepat tentang kesadaran (Titchener, 1921: 164). Jadi, bagi Wundt, psikologi eksperimental adalah studi terhadap kesadaran secara langsung dibantu oleh protokol eksperimental ilmu alam.

Wundt (1904: 626) memandang objek psikologi adalah kesadaran (consciousness), sebagai lawan dari penyelidikan fisiologis atau psikofisik. Wundt mendefinisikan kesadaran sebagai "pengalaman batin" (inner experiencee) yang berupa hanya fenomena "kenyataan langsung" (immediately real) yang membentuk pengalaman, dan bukan di balik atau di luarnya. Wundt menempatkan dirinya sebagai seorang empirisis radikal dalam hal ini. Subjek psikologi itu sendiri ditentukan sepenuhnya dan secara eksklusif oleh predikatnya, dan predikat ini semata-mata berasal dari pengamatan internal langsung. Oleh karena itu, domain dasar penyelidikan adalah individu sehingga disebut "psikologi individual" yaitu konten mental konkret yang muncul pada manusia tertentu, dan bukan substansi mental atau kumpulan fakultas. Wundt memandang bahwa psikologi individual harus menjadi ilmu melalui manipulasi eksperimental fenomena mental.

Inovasi Wundt adalah usaha untuk memproyeksikan ketelitian eksperimentasi fisiologi ke dalam domain pengalaman batin dengan melengkapi eksperimen ini serangkaian prosedur yang murni psikologis. Prosedur-prosedur ini membentuk metode 
yang terkenal yaitu "introspeksi" atau lebih tepatnya "pengamatan diri". Psikologi harus dimulai dengan pengamatan diri karena pengalaman "batin" membedakan dirinya dari pengalaman "eksternal" berdasarkan kedekatannya (Boring, 1950: 320-321).

Wundt menyadari kritik bahwa pengamatan diri tampaknya tak terhindarkan atas sisi paradoks dari subjek yang mengamati dan objek yang diamati. Wundt berusaha keras untuk membedakan gagasannya tentang pengamatan diri dari kebanyakan pendukung pandangan psikologi empiris, yang oleh Wundt disebut "sumber delusi diri" (Selbsttäuschungen). Wundt (1921: 162) percaya bahwa seseorang dapat mengoreksi masalah ini secara eksperimental dengan menggunakan sebanyak mungkin proses tak terduga, proses yang tidak disengaja, tetapi seperti tanpa disadari menampilkan diri (sich darbieten). Dengan kata lain, seseorang dapat secara acak dan berulang kali memunculkan fenomena kesadaran yang telah ditentukan sebelumnya secara tepat melalui eksperimen, subjek eksperimen, dan berbagai instrumen, dalam kondisi laboratorium yang terkendali.

Wundt berpendapat psikologi tidak tertarik pada hubungan psikofisik antara mekanisme indera somatik atau saraf dan fenomena "mental" yang ditimbulkan, tetapi semata-mata dalam menggambarkan dan jika mungkin "mengukur" keteraturan psikologis yang dapat diungkapkan oleh eksperimen semacam itu, yaitu hubungan sebab akibat teratur dalam domain psikis saja karena dalam hal ini subjek yang mengamati bertepatan dengan objek yang diamati, jelas bahwa arah perhatian pada fenomena ini mengubahnya. Wundt (1921: 165) memandang eksperimeneksperimen psikologis dengan demikian menyelidiki kesadaran persis seperti yang dilakukan eksperimen-eksperimen ilmu alam terhadap fenomena alam. Eksperimen-eksperimen itu tidak meninggalkan kesadaran pada dirinya sendiri, tetapi memaksanya untuk menjawab pertanyaan-pertanyaan para eksperimenter, dengan menempatkannya di bawah kondisi-kondisi yang diatur. Hanya dengan cara ini pengamatan (psikologis) [sebagai lawan dari sekadar persepsi $\{$ Wahrnehmung\}] yang mungkin dalam pengertian 
ilmiah, yaitu perhatian penuh dan pencarian yang teratur terhadap fenomena.

Wundt memandang kemungkinan psikologi fisiologis (sebagai lawan dari penyelidikan fisiologis murni ke dalam sensasi, perilaku, pembelajaran, dan sebagainya) bergantung pada kemungkinan pengamatan diri. Pengamatan diri pada gilirannya hanya berguna secara ilmiah jika urutan fenomena kesadaran "batin" dianggap berada di bawah prinsip kausalitas psikis yang independen, karena jika tidak demikian maka fenomena ini tidak akan pernah lebih dari kekacauan yang tidak memungkinkan bagi sains. Jika fenomena "batin" dapat ditunjukkan berada di bawah kausalitas fisik ilmu-ilmu alam, maka tidak diperlukan metode psikologis khusus, seperti pengamatan diri. Wundt menunjukkan fakta bahwa sistem kausalitas psikis dapat ditentukan yang tidak dapat direduksi menjadi kausalitas fisik. Wundt (1894: 43) menyatakan bahwa "tidak ada hubungan proses-proses fisik yang dapat mengajarkan apa pun tentang pola hubungan antara elemenelemen psikologis". "Fakta" ini menurut Wundt diberikan dalam eksperimen psiko-fisiologis yang dijelaskan di atas, membawanya ke apa yang disebut prinsip paralelisme psikofisik (PPP).

Perhatian Wundt tidak hanya dengan memperluas fakta psikologis yang diketahui, tetapi juga dengan menafsirkannya dalam kerangka penjelasan yang tepat. Kebutuhan untuk membangun kerangka tertutup tersebut yang berbeda dari fisiologi sama dengan membedakan kausalitas psikologis dari kausalitas fisik pada umumnya, dan karenanya psikologi dari ilmu-ilmu alam. Psikologi harus didefinisikan berbeda dengan dua bidang lain dari penyelidikan "ilmiah" (wissenschaftlich); pertama, Geisteswissenschaften atau "ilmu manusia", dan kedua, domain filsafat non-psikologis. Hubungan-hubungan keempat bidang ini (psikologi, filsafat, ilmu alam, ilmu manusia) tidak dapat direduksi, keterpaduan ini bukanlah suatu sistem metafisika atau ontologis, tetapi hanya salah satu fungsi penjelas (dan metodologi yang sepadan). Mereka tidak memiliki objek yang berbeda, tetapi hanya 
mewakili cara untuk menggambarkan perspektif yang tidak dapat direduksi pada objek yang sama, yaitu pengalaman.

\section{Prinsip-Prinsip Kemunculan Disiplin Ilmiah}

Psikologi merupakan salah satu disiplin ilmiah dalam lapangan penyelidikan kontemporer. Tulisan ini dilandasi pandangan bahwa ada prinsip-prinsip di balik pemikiran Wilhelm Wundt tentang psikologi, yang menandai kemunculan disiplin tersebut. Prinsip-prinsip itu dapat diabstraksi menjadi kaidah yang diperlukan untuk memandang kemunculan disiplin ilmiah. Penelitian ini mengandaikan bahwa prinsip-prinsip tersebut dapat diimplementasikan pada berbagai lapangan penyelidikan untuk menghasilkan disiplin ilmiah yang baru. Asumsi tersebut dapat dibuktikan dengan menggunakan pendekatan filsafat ilmu.

Filsafat ilmu merupakan cabang filsafat yang secara khusus menelaah tentang hakikat ilmu. Filsafat ilmu disebut juga sebagai ilmu tentang ilmu. Filsafat ilmu menguraikan sejarah pemikiran tentang ilmu. Sejarah ini mengungkapkan berbagai macam pemikiran tentang aspek-aspek yang mendalam sebuah ilmu, tak terkecuali kemunculan sebuah disiplin ilmiah. Sejarawan ilmu, George Sarton (1936) berpendapat bahwa akuisisi dan sistematisasi pengetahuan positif adalah satu-satunya kegiatan manusia yang sungguh-sungguh kumulatif dan progresif, serta kemajuan tidak memiliki makna yang pasti dan tidak dapat dipertanyakan kecuali dalam bidang ilmiah.

Pandangan tradisional tentang pengetahuan ilmiah kumulatif ditentang oleh banyak filsuf ilmu pada tahun 1960-an dan 1970-an, yang dengan demikian gagasan tentang kemajuan juga menjadi persoalan dalam filsafat ilmu. Niiniluoto (2019) menyatakan bahwa perdebatan tentang konsep normatif kemajuan pada saat yang sama berkaitan dengan pertanyaan aksiologis tentang maksud dan tujuan ilmu. Tugas analisis filosofis adalah mempertimbangkan jawaban alternatif atas pertanyaan: Apa yang dimaksud dengan kemajuan dalam ilmu? Pertanyaan konseptual ini kemudian dapat dilengkapi 
dengan pertanyaan metodologis: Bagaimana seseorang dapat mengenali perkembangan progresif ilmu? Sehubungan dengan definisi kemajuan dan penjelasan tentang indikatornya, kemudian dapat dipelajari pertanyaan faktual yaitu, sejauh mana dan dalam hal apa ilmu progresif?

Kemunculan disiplin ilmiah telah lama menjadi perhatian para filsuf ilmu. Tak sedikit dari filsuf ilmu menempatkannya sebagai titik tolak pemikirannya tentang ilmu. Hal itu berkaitan dengan salah satu kodrat ilmu yang bersifat mengalami perkembangan. Gagasan bahwa ilmu adalah usaha kolektif para peneliti dalam generasi-generasi yang berurutan merupakan ciri dari Zaman Modern (Nisbet, 1980). Empirisis klasik (seperti Francis Bacon) dan rasionalis (René Descartes) abad ke-17 mendesak agar penggunaan metode penyelidikan yang tepat menjamin penemuan dan pengujian kebenaran baru. Pandangan kumulatif tentang kemajuan ilmiah ini merupakan unsur penting dalam optimisme Pencerahan abad ke-18, dan dimasukkan dalam program positivisme Auguste Comte pada tahun 1830-an dengan mengumpulkan kebenaran yang disertifikasi secara empiris, ilmu juga mempromosikan kemajuan dalam masyarakat.

Tren berpengaruh lainnya di abad ke-19 adalah visi Romantis tentang pertumbuhan organik dalam budaya, laporan dinamis Hegel tentang perubahan sejarah dan teori evolusi. Mereka semua mengilhami pandangan epistemologis (seperti di antara kaum Marxis dan pragmatis) yang menganggap pengetahuan manusia sebagai suatu proses. Filsuf-ilmuwan dengan minat dalam sejarah ilmu seperti William Whewell, Charles Peirce, Ernst Mach, Pierre Duhem, memberikan analisis menarik dari beberapa aspek perubahan ilmiah (Niiniluoto, 2019).

Para filsuf analitis mulai menerapkan logika modern untuk mempelajari ilmu pada awal abad ke-20. Fokus utama mereka adalah struktur teori ilmiah dan pola inferensi (Suppe, 1977). Penyelidikan "sinkronis" terhadap "produk" kegiatan ilmiah dipertanyakan oleh para filsuf yang ingin memberikan perhatian serius pada studi "diakronis" tentang perubahan ilmiah (Niiniluoto, 
2019). Kontribusi tersebut antara lain Patterns of Discovery karya N.R. Hanson (1958), The Logic of Scientific Discovery (1959) dan Conjectures and Refutations (1963) karya Karl Popper, The Structure of Scientific Revolutions (1962) karya Thomas Kuhn, tesis ketidakterbandingan (incommensurability) Paul Feyerabend (1962), Methodology of Scientific Research Programmes Imre Lakatos (Lakatos dan Musgrave 1970), dan Progress and Its Problems (1977) karya Larry Laudan. Model epistemologi evolusioner Darwinis didukung oleh Popper dalam bukunya, Objective Knowledge: An Evolutionary Approach (1972), dan Human Understanding (1972) karya Stephen Toulmin (1972).

Karya-karya tersebut menantang pandangan umum yang diterima tentang perkembangan pengetahuan ilmiah dan rasionalitas. Falsifikasionisme Popper, laporan Kuhn tentang revolusi ilmiah, dan tesis Feyerabend tentang varian makna, berbagi pandangan bahwa ilmu tidak tumbuh hanya dengan mengumpulkan kebenaran-kebenaran baru yang mapan di atas kebenaran-kebenaran lama. Perubahan teori tidak kumulatif atau berkelanjutan artinya hasil pengetahuan ilmiah sebelumnya akan ditolak, diganti, dan ditafsirkan kembali oleh teori dan kerangka konseptual baru. Popper dan Kuhn, bagaimanapun berbeda dalam definisi mereka tentang kemajuan. Popper mengajukan gagasan bahwa teori-teori yang berurutan dapat mendekati kebenaran, sedangkan Kuhn mencirikan kemajuan dalam hal kapasitas pemecahan masalah teori (Niiniluoto, 2019).

Karl R. Popper menunjukkan bukti sejarah tentang perkembangan ilmu pengetahuan tidak dengan jalan akumulasi tetapi melalui proses error elimination, dengan mencontohkan koreksi yang dilakukan oleh Einstein terhadap fisika Newton. Popper memandang kemajuan ilmu pengetahuan tidak bersifat akumulatif dari waktu ke waktu, tetapi terjadi akibat adanya eliminasi yang semakin ketat terhadap kemungkinan salahnya. Pengembangan ilmu dilakukan dengan melalui uji-hipotesis sehingga dapat ditunjukkan kesalahannya, dan ilmu itu akan dibuang atau diabaikan jika memang salah. Begitu seterusnya, 
setiap ilmu atau teori yang baru akan dilakukan uji-hipotesis, dan jika semakin menunjukkan kesalahannya akan diabaikan dan diganti dengan teori yang baru (Komaruddin, 2016: 452-455).

Aktivitas keilmuan dengan demikian pada dasarnya hanya bersifat mengurangi kesalahan sampai sejauh mungkin mendekati kebenaran yang objektif (Komaruddin, 2016: 455). Oleh karena itu pengembangan ilmu dilakukan dengan merontokkan teori karena terbukti salahnya untuk kemudian digantikan dengan teori baru. Falsifikasi menjadi alat penentu demarkasi, yakni pembeda antara apa yang oleh Popper dinamakan genuine science (ilmu asli) dan apa yang disebutnya dengan pseudo science (ilmu tiruan).

Popper mengatakan: "science is revolution in permanence and criticism is the heart of the scientific enterprise" (Sains adalah revolusi permanen dan kritik adalah jantung dari usaha ilmiah). Jadi, kriteria keilmiahan sebuah ilmu atau teori adalah ilmu atau teori itu harus dapat disalahkan (falsibility), dapat disangkal (refutability), dan dapat diuji (testability). Gagasannya telah mengantarkannya dikenal sebagai seorang epistemologi rasional-kritis dan empirisis modern (Komaruddin, 2016: 455).

Thomas Kuhn menolak pandangan tradisional dan Popperian tentang perubahan dalam ilmu. Jika revolusi ilmiah dipandang seperti sains normal tetapi lebih baik, maka sains revolusioner akan selalu dianggap sebagai sesuatu yang positif, untuk dicari, dipromosikan, dan disambut. Revolusi dalam pandangan Popper bukan karena menambah pengetahuan positif tentang kebenaran teori tetapi karena mereka menambah pengetahuan negatif bahwa teori-teori yang relevan itu salah. Thomas Kuhn mengklaim bahwa sains normal dapat berhasil membuat kemajuan hanya jika ada komitmen kuat oleh komunitas ilmiah yang relevan terhadap kepercayaan teoretis, nilai, instrumen dan teknik, dan bahkan metafisika yang mereka miliki. Konstelasi komitmen bersama ini pada satu titik disebut 'matriks disiplin' (Kuhn, 1970: 182). Kuhn lebih sering menyebutnya menggunakan istilah 'paradigma'.

Penekanan Kuhn yang tidak biasa pada sikap konservatif membedakannya tidak hanya dari unsur heroik dari gambaran 
standar tetapi juga dari Popper dan penggambarannya tentang ilmuwan yang selamanya berusaha untuk menyangkal teorinya yang paling penting. Ketegangan antara keinginan untuk inovatif dan konservatif yang diperlukan dari sebagian besar ilmuwan adalah subjek dari salah satu esai pertama Kuhn dalam teori sainsnya, "The Essential Tension" (1959). Penanaman komitmen menjadi elemen kunci dalam pelatihan ilmiah dan dalam pembentukan pola pikir ilmuwan yang sukses karena komitmen pada 'matriks disiplin' (paradigma) adalah prasyarat untuk sains normal yang sukses.

Rizal Mustansyir (2007: 267) dalam penelitiannya yang berjudul "Program Riset Imre Lakatos" mengungkapkan pandangan Lakatos tentang bentuk ilmu dalam proses perkembangannya. Mustansyir menyatakan bahwa Lakatos membedakan antara ilmu yang matang (mature science) dan ilmu yang belum matang (immature science). Ilmu yang sudah matang ditandai dengan program riset, sedangkan ilmu yang belum matang lebih ditandai dengan pola uji coba (trial and error).

Lakatos mendiskusikan persoalan penilaian objektif tentang perkembangan ilmiah dalam istilah pergeseran persoalan yang maju dan merosot dalam rangkaian teori ilmiah. Hal terpenting pada setiap rangkaian dalam perkembangan ilmiah itu bahwa perkembangan itu dikarakterisasi melalui satu kontinuitas yang pasti yang melibatkan hubungan antar-anggotanya. Kontinuitas ini berkembang dari satu program riset yang sungguh-sungguh yang dibayangkan pada awalnya. Program itu terdiri atas aturan metodologis: beberapa ahli menceritakan pada ilmuwan langkahlangkah penelitian apa yang harus dihindari (heuristic negative), sedangkan ahli yang lain menunjukkan langkah-langkah riset apa yang harus dikerjakan (heuristic positive) (Mustansyir, 2007: 267268).

Studi-studi atas perubahan dalam ilmu menyebabkan banyak hal baru yang penting ditambahkan ke kotak peralatan para filsuf ilmu (Niiniluoto, 2019). Salah satunya adalah studi sistematis tentang hubungan antar teori seperti: reduksi, korespondensi, dan revisi keyakinan. Hal lainnya adalah pengakuan bahwa selain 
pernyataan dan teori individu, ada juga kebutuhan untuk mempertimbangkan unit-unit aktivitas dan pencapaian ilmiah yang berkembang secara temporal: sains normal yang diarahkan oleh paradigma Kuhn, program penelitian Lakatos, tradisi penelitian Laudan, dinamika Wolfgang Stegmüller (1976), teori evolusi dan praktik konsensus menurut Philip Kitcher (1993). Alat baru yang digunakan dalam banyak pembelaan pandangan realis tentang kemajuan ilmiah adalah gagasan keserupaan kebenaran atau verisimilitude (penampakan kebenaran) (Popper, 1963 \& 1970).

Ilmu adalah sistem kompleks berlapis-lapis yang melibatkan komunitas ilmuwan yang terlibat dalam penelitian menggunakan metode ilmiah untuk menghasilkan pengetahuan baru. Pengertian ilmu dapat merujuk pada institusi sosial, peneliti, proses penelitian, metode penyelidikan, dan pengetahuan ilmiah. Konsep kemajuan dapat didefinisikan secara relatif terhadap masing-masing aspek ilmu ini. Oleh karena itu, berbagai jenis kemajuan dapat dibedakan relatif terhadap ilmu, misal: ekonomi (peningkatan dana penelitian ilmiah), profesionalisme (meningkatnya status ilmuwan dan institusi akademik mereka di masyarakat), pendidikan (peningkatan keterampilan dan keahlian para ilmuwan), metodis (penemuan metode penelitian baru, penyempurnaan instrumen ilmiah), dan kognitif (peningkatan atau kemajuan pengetahuan ilmiah). Jenis kemajuan ini harus dibedakan secara konseptual dari kemajuan dalam kegiatan manusia lainnya, meskipun mungkin ternyata kemajuan ilmiah memiliki setidaknya beberapa koneksi faktual dengan kemajuan teknologi (peningkatan efektivitas alat dan teknik) dan kemajuan sosial (kemakmuran ekonomi, kualitas kehidupan, keadilan dalam masyarakat). Semua aspek kemajuan ilmiah melibatkan pertimbangan yang berbeda sehingga tidak ada konsep tunggal yang akan mencakup semuanya (Niiniluoto, 2019). Tujuan penelitian ini untuk berkonsentrasi hanya pada kemajuan kognitif, yaitu untuk memberikan penjelasan tentang kemajuan ilmu pada keberhasilannya dalam pencarian pengetahuan atau pencarian kebenaran. 
Ilmu dengan demikian senantiasa mengalami perubahan meskipun masih mengandung unsur-unsur yang tetap. Unsurunsur tetap dalam perubahan ilmu inilah yang merupakan prinsipprinsip yang menjamin identitas ilmu itu sendiri, tetapi di sisi lain ada juga prinsip-prinsip yang menandai perubahan ilmu itu sendiri. Perubahan ilmu hingga saat ini pun masih menjadi persoalan di kalangan para filsuf, apakah berupa kemajuan ataukah perkembangan? Pertanyaan itu tak menyangsikan munculnya disiplin ilmiah baru dalam sejarah ilmu. Beberapa filsuf sebagaimana dikemukakan di atas telah mencoba untuk menjelaskan fenomena kemunculan disiplin ilmiah tersebut. Karl Popper dengan gagasan falsifikasionisme-nya, Thomas Kuhn dengan pandangan revolusi ilmiah-nya, Imre Lakatos dengan pendapat program riset-nya. Beberapa pandangan dari para filsuf tersebut mengindikasikan adanya kesamaan yang dapat ditarik menjadi prinsip dalam fenomena perubahan ilmu. Kesamaan itu berupa prinsip dalam terjadinya gerak ilmu yaitu: kebaruan, kekhasan, heuristik, dan revolusioner.

Apakah prinsip-prinsip tersebut terdapat juga dalam peristiwa kemunculan psikologi sebagai disiplin ilmiah yang ditandai dengan pemikiran Wilhelm Wundt? Pertanyaan ini akan dibahas lebih lanjut pada subbab berikutnya

\section{Kriteria Perkembangan Ilmu di balik Proses Kelahiran \\ Psikologi}

Subbab sebelumnya telah menunjukkan salah satu karakteristik ilmu yang senantiasa mengalami perubahan. Perubahan ilmu tak berarti tanpa persoalan. Satu persoalan yang timbul dari sifat perubahan ilmu ialah, "apa yang menjamin sesuatu sehingga masih dapat dianggap sebagai ilmu?" Jawaban atas persoalan itu merupakan prinsip yang dapat dipegang untuk menandai keberadaan ilmu. Penelaahan lebih mendalam terhadap prinsip-prinsip tersebut akan menimbulkan persoalan lebih lanjut misal, "apa yang menandai perubahan di dalam ilmu itu sendiri?" 
Jawaban atas persoalan tersebut meyediakan rujukan tentang prinsip dalam perubahan ilmu.

Ilmu sering kali dibedakan dari domain budaya manusia lainnya karena sifatnya yang progresif berbeda dengan seni, agama, filsafat, moralitas, dan politik. Ada standar atau kriteria normatif yang jelas untuk mengidentifikasi perbaikan dan kemajuan dalam ilmu (Niiniluoto, 2019). Oleh karena itu, prinsip-prinsip tersebut sekaligus dapat menjadi kriteria dalam menjustfikasi kemunculan sebuah disiplin ilmiah. Prinsip-prinsip tersebut antara lain: kebaruan, kekhasan, heuristik, dan revolusioner. Fokus penelitian ini adalah menganalisis prinsip-prinsip kemunculan disiplin ilmiah tersebut dalam peristiwa kelahiran psikologi yang ditandai dengan pemikiran Wilhelm Wundt.

Subbab ini difokuskan pada upaya menjelaskan beberapa asumsi berikut:

1. Ada kebaruan dalam pemikiran Wundt yang membuat penerimaan terhadap psikologi ilmiah.

2. Pemikiran Wundt memiliki kekhasan sehingga memberi corak pada psikologi sebagai ilmu baru pada masanya.

3. Kemunculan psikologi tidak terlepas dari konteks pengetahuan sebelumnya yang berarti mengandung sisi heuristik.

4. Psikologi ilmiah muncul secara revolusioner.

Kebaruan dalam kemunculan disiplin ilmiah tampaknya merupakan sesuatu yang tak terbantahkan. Hal itu berarti bahwa dalam setiap kemunculan disiplin ilmiah tentu ada sesuatu yang baru. Tak mungkin terjadi kemunculan disiplin ilmiah jika tak ada sesuatu yang baru. Jika pemikiran Wundt dianggap sebagai tonggak sejarah (milestone) psikologi ilmiah berarti ada yang baru dalam pemikiran Wundt. Persoalannya adalah apa yang baru dari pemikiran Wundt tentang psikologi sehingga dipandang sebagai momentum kemunculan disiplin baru tersebut di kemudian hari? Saulo de Freitas Araujo (2015: 22) menjawab persoalan tersebut dengan menyatakan bahwa Wundt telah menemukan kesatuan 
teoritis dan konseptual baru dalam sistem psikologisnya yang matang.

Danziger (1980: 109) menyatakan bahwa Wundt memprakarsai program penelitian (research proggramme) psikologi sistematis pertama. Pencapaian ini bersamaan dengan penjabarannya tentang filsafat ilmu yang anti-induktivis dan menekankan pada prioritas motif penjelas. Penjelasan psikologis khusus bergantung pada konsep kausalitas psikologis seperti yang dimanifestasikan dalam proses aperseptif atau kehendak. Perbedaan utama antara Wundt dan model eksperimen psikologis lainnya dapat dipahami dengan pendekatan umum tersebut. Dengan demikian para peneliti dan subjek harus menjadi kolaborator yang tercerahkan dan peran introspeksi lebih signifikan dalam penjelasan dari pada dalam konteks pengamatan murni. Persyaratan khusus Wundt untuk eksperimen psikologis membuatnya menolak model awal lainnya seperti yang dicontohkan oleh eksperimen hipnosis di mana hubungan subjek eksperimen lebih dekat dengan apa yang menjadi norma di abad kedua puluh.

Kriteria perkembangan ilmu lainnya adalah heuristik. Apa yang dimaksud dengan heuristik? Heuristik, baik dalam arti aturan maupun metode, adalah aturan praktis, strategi, trik, penyederhanaan, atau jenis perangkat lainnya yang secara drastis membatasi pencarian solusi dalam ruang masalah yang besar. Heuristik tidak menjamin solusi optimal (pada kenyataannya tidak menjamin solusi sama sekali), semua yang dapat dikatakan untuk heuristik yang berguna adalah bahwa hal itu menawarkan solusi yang cukup baik pada sebagian besar waktu (Feigenbaum, 1963: 61).

Araujo (2015: 2) menyatakan bahwa tradisi psikologi Jerman yang panjang sebelum Wundt bukanlah hal baru. Istilah 'psikologi' muncul dalam budaya Jerman untuk pertama kalinya pada abad ke16, sebagian besar terkait dengan diskusi tentang De Anima karya Aristoteles atau keabadian jiwa. Istilah tersebut tidak bersifat univokal karena sering diselingi dengan istilah lain, seperti 'pneumatologi' dan 'antropologi' yang tidak menunjuk bidang 
pengetahuan yang independen atau baru. Psikologi Wundt sebagai bagian dari cita-cita epistemik tertingginya, yang filosofis dalam esensinya. Kontekstualisasi diperlukan untuk menunjukkan bahwa dalam mendekati proyek psikologis Wundt, seseorang harus memperhitungkan latar belakang yang kompleks.

Bunn (2017: 11) memandang bahwa ada ironi pada reputasi Wundt sebagai bapak yang setia pada ilmu yang baru lahir (psikologi) bahwa dia sama sekali tidak memiliki keinginan untuk membawa disiplin psikologi baru ke dunia. Tujuan utamanya adalah merevitalisasi filsafat menggunakan metode fisiologis untuk menghasilkan data tentang kemampuan pikiran manusia. Wundt tidak meninggalkan warisan abadi baik penemuan empiris atau prinsip-prinsip teoretis, terlepas dari produktivitasnya yang legendaris. Oleh karena itu, Wundt meninggalkan teka-teki yang membingungkan yaitu metode yang tampaknya membangun kepercayaan terhadap keilmiahan psikologi, tidak menghasilkan penemuan apa pun yang telah teruji oleh waktu. Bunn (2017: 11) menyatakan bahwa Wundt benar bahwa psikologi ada di 'batas yang agak mencurigakan' antara dua aspek fisiologi dan filsafat. Kedua aspek visinya untuk psikologi ini masing-masing melihat ke arah yang berbeda melintasi perbatasan itu.

Pendapat di atas menunjukkan bahwa pemikiran Wundt tentang psikologi yang kemudian dianggap sebagai tonggak kelahiran disiplin ilmiah tersebut tidak tercerabut dari akar konteks pada zamannya. Hal itu menunjukkan karakter heuristik dari pemikiran Wundt tentang psikologi. Dengan demikian berarti ada prinsip heuristik dalam proses kelahiran psikologi yang ditandai oleh pemikiran Wundt. Oleh karena itu dapat dinyatakan bahwa salah satu prinsip kelahiran disiplin ilmiah dalam pemikiran Wundt tentang psikologi adalah heuristik. Hal itu menunjukkan juga bahwa dalam setiap perkembangan ilmu perlu ada sifat heuristik di balik kebaruannya.

Kriteria berikutnya dalam perkembangan ilmu adalah kekhasan. Araujo (2015: 35) mendefinisikan kekhususan eksperimen psikologis Wundt yang menekankan bahwa meskipun 
rangsangan sensorik sangat penting, mereka hanya alat eksperimental yang berguna, manipulasi yang berfungsi untuk mengakses hukum kehidupan mental, dan tidak pernah menjadi pusat penyelidikan, yang murni psikologis pada intinya. Wundt pada saat yang sama menekankan perbedaan antara psikologi eksperimental dan psikofisika. Terlepas dari pentingnya hukum Fechner untuk domain mental, Wundt ingin membedakan antara dua usaha ilmiah, menegaskan bahwa psikologi eksperimental memiliki tujuan yang sangat khusus, yaitu asal-usul atau perkembangan proses mental.

Pernyataan Araujo (2015) di atas menunjukkan sisi kekhasan pemikiran Wilhelm Wundt tentang psikologi. Hal itu menegaskan bahwa ada prinsip kekhasan dalam pemikiran Wundt yang menandakan kemunculan psikologi sebagai disiplin ilmiah. Dengan kata lain, perkembangan ilmu tidak dapat dipisahkan dari kekhasan tertentu. Setiap upaya pengembangan ilmu membutuhkan spesifikasi khusus, atau setidaknya menunjukkan kekhasan yang tidak terungkap pada teori atau bentuk-bentuk turunan ilmu sebelumnya.

Klaim penelitian ini tidak terlalu berlebihan jika menyatakan bahwa kemunculan psikologi yang ditandai oleh pemikiran Wilhelm Wundt merupakan salah satu bentuk revolusi ilmiah. I. B. Cohen (1985: 52) meletakkan empat uji sejarah, empat kondisi yang diperlukan, untuk penanda yang benar dari sebuah revolusi dalam ilmu. Pertama, para ilmuwan yang terlibat dalam pembangunan harus melihat diri mereka sebagai revolusioner, dan orang-orang sezaman yang relevan harus setuju bahwa sebuah revolusi sedang berlangsung. Kedua, dokumen sejarah harus menghitungnya sebagai sebuah revolusi. Ketiga, para sejarawan dan filsuf kemudian harus setuju dengan penentuan ini dan, keempat, para ilmuwan di kemudian hari harus bekerja di bidang itu atau penerusnya.

Thomas Nickles (2015) menyatakan bahwa Cohen mengecualikan orang-orang yang mengklaim diri mereka sebagai revolusioner pada zamannya tetapi memiliki dampak yang tidak 
memadai di lapangan untuk mempertahankan penilaian sejarah dengan memasukkan laporan dari waktu dugaan revolusi dan penilaian historiografis kemudian. Cohen juga waspada terhadap pemberian keterangan revolusi kepada orang-orang yang tidak tahu bahwa mereka adalah revolusioner. Empat contoh revolusi ilmiah besar menurut Cohen memiliki dimensi institusional: Revolusi Ilmiah menampilkan kebangkitan masyarakat dan jurnal ilmiah, yang kedua adalah revolusi pengukuran yang disebutkan di atas dari sekitar 1800 hingga 1850 (Kuhn juga menyebutnya "revolusi ilmiah yang kedua"). Ketiga, munculnya penelitian pascasarjana universitas menjelang akhir abad itu. Keempat, ledakan pasca-Perang Dunia II dalam pendanaan pemerintah untuk ilmu pengetahuan dan lembaga-lembaganya.

Persoalannya kemudian ialah bagaimana dengan pemikiran Wundt? Apakah memenuhi kriteria revolusi ilmiah sebagaimana digambarkan di atas? Daniel N. Robinson (1995: 279) menyatakan bahwa bahkan hari ini seseorang tidak dapat membaca buku Wundt Principles of Physiological Psychology" tanpa terkesan oleh kepekaannya pada masalah eksperimental, filosofis, dan biofisik yang secara unik mempengaruhi ilmu baru. Dari sekian banyak karyanya, yang satu ini yang paling penting. Karya itu bukan hanya salah satu dari yang pertama (dan salah satu dari sedikit) bukunya yang diterjemahkan ke dalam bahasa Inggris. Hal ini merupakan pembuktian bahwa karya Wundt memiliki pengaruh signifikan pada generasi saat ini dalam mempelajari psikologi.

Alan Kim (2016) menyatakan bahwa dalam mendirikan psikologi sebagai ilmu eksperimental, Wundt pada dasarnya melakukan "triangulasi" media melalui beberapa pilihan yang tersedia yaitu menolak mistisisme Fechner sambil mempertahankan pendekatan eksperimentalnya, serta pada saat yang sama melampaui interpretasi fisik murni dari eksperimen fisiologis ala Helmholtz, dengan argumen bahwa setidaknya eksperimen pada manusia dapat mengungkapkan hukum seperti keteraturan realitas mental (psikologis). Daya tarik Wundt, baik bagi para sarjana sejarah filsafat maupun para filsuf pemikiran kontemporer, pada 
akhirnya mengalir dari definisi, metodologi, dan "metafisika" psikologi-fisiologis ini. Pemikiran Wundt tentang psikologi dengan demikian layak dipandang sebagai salah satu momen revolusi dalam ilmu

\section{SIMPULAN}

Visi Wilhelm Wundt terhadap psikologi memenuhi kriteria untuk menjadi sebuah disiplin ilmiah baru pada masanya dan membuatnya layak menyandang gelar sebagai penemu psikologi ilmiah. Pemikiran Wundt dalam sistem yang lengkap mengungkap sistem kausalitas psikis yang dapat ditentukan dari eksperimen psiko-fisiologis membawanya ke apa yang disebut prinsip paralelisme psikofisik. Hal ini yang kemudian memungkinkan penyelidikan ilmiah psikologis.

Kondisi-kondisi yang mendukung (sufficient condition) bagi lahirnya psikologi yaitu situasi ilmiah dan pengetahuan awal yang memadai. Hal itu terlacak pada perkembangan teori filsafat, fisiologi, pada masanya. Lingkungan akademik yang mendukung, instrumen penelitian, antusiasme dan intensitas pemikir dan Ilmuwan yang tercermin dari usaha Wundt. Selain itu, diskursus wacana pengetahuan antara rasionalisme dan empirisisme yang ditengahi merupakan pra kondisi kelahiran psikologi ilmiah.

Syarat-syarat yang dipenuhi (necessary condition) dalam kelahiran psikologi yang dapat berlaku juga bagi 'penemuan' ilmu lain di masa mendatang dan sekaligus merupakan prinsip dalam kemunculan disiplin ilmiah yaitu: kebaruan, spesialisasi, kekhasan, heuristik, dan revolusioner. Prinsip-prinsip ini senantiasa menyertai dalam kemunculan sebuah disiplin ilmiah sebagaimana yang diungkap oleh filsuf ilmu lainnya seperti Karl Popper, Thomas Kuhn, Imre Lakatos. Kajian ini merupakan cara pandang baru yang ditawarkan tentang perubahan ilmu (scientific change) sebagai alternatif atas pandangan epistemologi klasik antara rasionalisme Descartes dan empirisisme Francis Bacon dari abad ke-17 yang menjadi bahan utama program positivisme Auguste Comte. 
Hasil penelitian yang diungkap dalam tulisan ini diharapkan menjadi rujukan dalam usaha pengembangan sebuah disiplin ilmiah maupun pengembangan ilmu ke depannya. Hal ini memberi pemahaman tentang karakteristik ilmu yang senantiasa bergerak namun mengandung hal-hal yang tetap. Gerak tersebut masih menjadi salah satu persoalan utama filsafat ilmu hari ini, apakah berupa kemajuan atau perkembangan? persoalan ini membuka ruang penyelidikan lebih lanjut baik bagi kalangan sejarawan sains maupun filsuf ilmu.

\section{DAFTAR PUSTAKA}

Araujo, D. S. (2015). Wundt and The Philosophical Foundations of Psychology: A Reappraisal. London: Springer.

Ben-David, J., \& Collins, R. (1966). Social factors in the origins of a new science: the case of psychology, American Sociological Review, 31(4): 451-65.

Boring, E.G. (1950). A History of Experimental Psychology, 2nd ed. New York: Appleton-Century-Crofts.

Bunn, G. C. (2017). Wilhelm Wundt and The Emergence of Scientific Psychology. Psychology Review, 22(3), pp.10-12.

Cohen, I. B. (1985). Revolution in Science. Harvard: Harvard University Press.

Danziger, K. (1980). Wundt's Psychological Experiment in The Light of His Philosophy of Science. Psychological Research, 42(1), pp.109-122.

Feigenbaum, E. A., \& Feldman, J. (Eds.). (1963). Computers and Thought. McGraw-Hill Inc., New York.

Hastjarjo, T. D. (2009). Peran Laboratorium dalam Mempelajari Perilaku Manusia. Buletin Psikologi, 17(2).

Hilgard, E. R. (1987). Psychology in America: A Historical Survey.

Orlando: Harcourt Brace Yovanovich Publisher.

Jahja, Y. (2011). Psikologi Perkembangan. Yogyakarta: Kencana.

Kim, Alan. (2016). "Wilhelm Maximilian Wundt", The Stanford Encyclopedia of Philosophy (Fall 2016 Edition), Edward N. 
190 Jurnal Filsafat, Vol. 31, No. 2, Agustus 2021

Zalta (Ed.),

URL $=$ $<$ https://plato.stanford.edu/archives/fall2016/entries/wilhelmwundt $/>$.

Kitcher, P. (1990). Kant's Transcendental Psychology. New York: Oxford.

Komarudin, K. (2016). Falsifikasi Karl Popper dan Kemungkinan Penerapannya dalam Keilmuan Islam. At-Taqaddum, 6(2), pp.444-465.

Kuhn, T. (1970). The Structure of Scientific Revolutions, Chicago: University of Chicago Press.

Leahey, T. H. (2018). A History of Psychology: From Antiquity to Modernity. Routledge: Routledge University Press.

Mustansyir, R. (2007). Program Riset Ilmiah Imre Lakatos. Jurnal Filsafat, 17(3), pp.250-269.

Nickles, T. (2017). "Scientific Revolutions", The Stanford Encyclopedia of Philosophy (Winter 2017 Edition), Edward N. Zalta (Ed.), URL $=$

$<$ https://plato.stanford.edu/archives/win2017/entries/scientificrevolutions/>.

Niiniluoto, I. (2019). "Scientific Progress", The Stanford Encyclopedia of Philosophy (Winter 2019 Edition), Edward N. Zalta (Ed.), URL $=$

$<$ https://plato.stanford.edu/archives/win2019/entries/scientificprogress/>.

Nisbet, R. (1980). History of The Idea of Progress. London: Heinemann. Reed, E. S. (1982). Descartes' Corporeal Ideas Hypothesis and The Origin of Scientific Psychology. The Review of Metaphysics, pp.731-752.

Rieber, R. (2013). Wilhelm Wundt and The Making of a Scientific Psychology. Springer Science \& Business Media.

Robinson, D. N. (1995). An Intellectual History of Psychology. University of Wisconsin Press.

Sarton, G. (1936). The Study of the History of Science. Cambridge: Harvard University Press.

Schultz, D. P., \& Sydney E.S. (2014). Sejarah Psikologi Modern. Terj: 
Lita Hardian. Bandung: Nusa Media.

Suppe, F. (Ed.) (1977). The Structure of Scientific Theories, 2nd ed. Urbana: University of Illinois Press.

Thagard, P. (Ed.) (2007). Philosophy of Psychology and Cognitive Science. North-Holland.

Titchener, E. B. (1921). Wilhelm Wundt. The American Journal of Psychology, 32(2), 161-178.

Weiten, W. (2017). Psychology: Themes and Variations. Boston: Cengage Learning.

Wundt, W. (1894). “Über psychische Kausalität und das Prinzip des psychophysischen Parallelismus", Philosophische Studien, Vol 10: $1-124$.

-----. (1904). Principles of Physiological Psychology, (trans.), diterjemahkan oleh E.B. Titchener dari Grundzüge der physiologischen Psychologie. London: Allen.

-----. (1921). Logik (vol. 3) The $4^{\text {th }}$ edition. Stuttgart: Enke. 